\title{
PERKEMBANGAN PARADIGMA DEMOKRASI PANCASILA DALAM PEMBANGUNAN HUKUM DI INDONESIA
}

\section{PANCASILA DEMOCRATIC PARADIGM IN INDONESIA LAW DEVELOPMENT}

\author{
Topan Indra Karsa \\ Fakultas Hukum Universitas Tulang Bawang Lampung \\ topan_lpg@yahoo.co.id
}

\begin{abstract}
Abstrak
Tujuan penelitian ini adalah menggali sejarah dan proses perkembangan serta penerapan demokrasi pancasila yang ada di Indonesia. Konsep Demokrasi Pancasila dalam pembangunan hukum di Indonesia berdasarkan pada kekeluargaan dan gotong-royong yang ditujukan kepada kesejahteraan rakyat, yang mengandung unsur-unsur berkesadaran religius, berdasarkan kebenaran, kecintaan dan budi pekerti luhur, berkepribadian Indonesia dan berkesinambungan. Metode penelitian yang digunakan adalah penelitian hukum normatif yaitu menggunakan bahan kepustakaan. Perkembangan demokrasi mengalami fluktuasi yang mempengaruhi sendi kehidupan bermasyarakat. Penerapan demokrasi Pancasila di Indonesia bercorak nasionalisme religius bukan kepada nasionalisme sekuler. Konsep demokrasi Pancasila tidak bersumber dari paham individualisme yang berkembang di barat, meski tak bisa di tampik bahwa nilai-nilai liberal yang membentuk demokrasi di barat seperti kesetaraan hak warga negara, kebebasan berpendapat sebagai pilar demokrasi yang utama berpengaruh kuat terhadap pengayaan demokrasi Pancasila.
\end{abstract}

\section{Kata Kunci: Demokrasi, Pancasila, Pembangunan Hukum}

\begin{abstract}
The purpose of this research is to explore the history and process of development and application of Pancasila democracy in Indonesia. The concept of Pancasila democracy in legal development in Indonesia is based on kinship and mutual cooperation aimed at the welfare of the people, which contains elements of religious awareness, based on truth, love and noble character, has an Indonesian personality and is sustainable. The research method used is normative legal research using library materials. The development of democracy experiences fluctuations that affect the joints of social life. The implementation of Pancasila democracy in Indonesia is characterized by religious nationalism, not secular nationalism. The concept of Pancasila democracy does not originate from the notion of individualism that has developed in the west, although it cannot be denied that liberal values that shape democracy in the west, such as equal rights for citizens, freedom of opinion as the main pillar of democracy have a strong influence on the enrichment of Pancasila democracy.
\end{abstract}

Keywords : Democracy, Pancasila, Legal Development 


\section{A. Pendahuluan}

Demokrasi sebagai suatu kebijakan dalam orientasi perubahan atas apa yang terjadi di masa lampau, mengembalikan hak menentukan peminpin kepada rakyat, penguasa di bawah pengawasan rakyat. Dalam sejarah ketatanegaraan Republik Indonesia yang telah lebih dari setengah abad, perkembangan demokrasi mengalami fluktuasi (pasang surut). Masalah pokok yang dihadapi oleh bangsa Indonesia adalah bagaimana upaya meningkatkan kehidupan ekonomi dan membangun kehidupan sosial politik yang demokratis dalam masyarakat yang plural. ${ }^{1}$

Paradigma demokrasi di Indonesia telah semakin berkembang seiring dengan pergantian pemimpin serta pergantian masa, mulai dari masa penjajahan, orde lama sampai kepada reformasi sekarang. Demokrasi kini telah akrab dengan kehidupan masyarakat Indonesia. Penerapan demokrasi pun telah merambat sampai hampir ke semua aspek, tak terkecuali pada perpolitikan di Indonesia. Demokrasi kini semakin gencar di pelajari

${ }_{1}^{1}$ Maulana Arafat Lubis, Hukum Tata Negara, (Medan: Akasha Sakti, 2018), hlm.50- 52 karena fungsinya yang begitu sangat dekat dengan keseharian. ${ }^{2}$

Hakikat demokrasi sebagai suatu sistem bermasyarakat dan bernegara serta pemerintahan berada di tangan rakyat mengandung tiga hal pengertian, diantaranya pertama, pemerintah dari rakyat (Government of the people), kedua, pemerintah oleh rakyat (Government by people), ketiga, pemerintahan untuk rakyat (Government for people). Hakikat suatu pemerintahan yang demokratis bila ketiga hal diatas dapat dijalankan dan ditegakkan dalam tata pemerintahan. Salah satu corak demokrasi yang diterapkan di Indonesia yakni Demokrasi Pancasila. Demokrasi Pancasila adalah demokrasi yang berdasarkan kekeluargaan dan gotongroyong yang ditujukan kepada kesejahteraan rakyat, yang mengandung unsur-unsur kesadaran religius, berdasarkan kebenaran, kecintaan dan budi pekerti luhur, berkepribadian Indonesia dan berkesinambungan. ${ }^{3}$

Kekuatan ideologi Pancasila bergantung pada kualitas tiga dimensi, yaitu:

\footnotetext{
${ }^{2}$ Nadrilun, Mengenal Lebih Dekat Demokrasi Di Indonesia, (Jakarta: PT Balai Pustaka, 2012), hlm 32

${ }^{3}$ Mohammad Hatta, Karya lengkap Bung Hatta.Buku I: Kebangsaan dan Kerakyatan, (Jakarta : Penerbit LP3ES, 1998), hlm. 87
} 
a. Dimensi realita, yaitu nilai-nilai dasar ideologi Pancasila telah mengakar dalam kehidupan masyarakat karena nilai-nilai tersebut bersumber dari pengalaman sejarah dan budaya bangsa (volkgeist/ jiwa bangsa).

b. Dimensi idealisme, yaitu nilai-nilai dasar ideologi Pancasila mengandung idealisme untuk menyongsong kehidupan masa depan yang lebih baik.

c. Dimensi fleksibilitas, yaitu ideologi Pancasila dengan keluwesannya sehingga memungkinkan munculnya pengembangan pemikiran-pemikiran baru yang relevan dengan Pancasila tanpa mengingkari hakekat yang terkandung dalam nilai dasar Pancasila. $^{4}$

Perwujudan demokrasi pancasila dalam pembangunan hukum di Indonesia tidak mengenal dominasi mayoritas ataupun tirani minoritas. Dominasi mayoritas adalah kelompok besar yang menguasai segala segi kehidupan berbangsa dan bernegara dengan mengabaikan kelompok yang kecil. Tirani minoritas adalah kelompok kecil yang menguasai segala segi kehidupan berbangsa dan bernegara dengan mengabaikan kelompok besar.

\footnotetext{
${ }^{4}$ Mubyarto, Buku Pancasila Sebagai Ideologi, (Jakarta: BP-7 Pusat, 1991), hlm.52
}

Pancasila sebagai ideologi memiliki karakteristik yang berbeda dengan ideologi lain seperti liberal atau komunis. Ideologi pancasila merupakan ideologi atau dasar negara Indonesia yang merupakan suatu kesepakatan luhur (modus vivendi) para pendiri negara. Pancasila mengandung ideologi yang nilai-nilainya digali dan diambil dari karakteristik dan kepribadian yang hidup di tengah-tengah masyarakat Indonesia yang dikristalisasikan menjadi dasar negara. Artinya sila-sila pancasila bukan sesuatu yang diada-adakan namun nilai-nilainya sudah hidup di tengahtengah masyarakat seperti nilai keagamaan, nilai keadilan, nilai persatuan, nilai permusyawaratan, nilai kegotongroyongan, nilai toleransi dan tenggang rasa.

Berdasarkan uraian di atas, maka penulis mengkaji mengenai proses perkembangan serta penerapan demokrasi pancasila yang ada di Indonesia dari dimensi hukumnya.

\section{B. Metode Penelitian}

Metode yang digunakan yakni metode penelitian normatif dengan memaknai norma-norma hukum yang tertulis sebagai sesuatu yang di cita-citakan dan bersifat preskriptif. Dalam rangka menjabarkan tujuan penelitian, maka digunakan pendekatan konstitusional (constitutional 
approach) dan pendekatan sejarah (historical approach). Kedua pendekatan tersebut memiliki arti penting untuk mendapatkan gambaran yang jelas mengenai sejarah perkembangan negara dan dinamika masyakat terkait dengan demokrasi Pancasila dalam pembangunan hukum.

Bahan hukum yang digunakan antara lain bahan hukum primer berupa UUD Negara Republik Indonesia 1945, bahan hukum sekunder berupa buku, jurnal terkait dengan demokrasi Pancasila. Bahan non-hukum juga digunakan dalam penelitian ini yakni buku atau jurnal bidang politik karena penelitian ini memiliki keterkaitan erat dengan dimensi politik di Indonesia. Bahan-bahan hukum maupun non hukum tersebut dianalisis menggunakan pendekatan konstitusional dan pendekatan sejarah sehingga bisa mendapatkan jawaban atas permasalahan yang diangkat dalam peneltian ini.

\section{Paradigma Demokrasi Pancasila Dalam Pembangunan Hukum Di Indonesia}

\section{Konsep Demokrasi}

Konsep demokrasi terkait erat dengan bidang ilmu politik dan digunakan sebagai indikator dalam perkembangan politik di suatu negara. Demokrasi memiliki hubungan dengan pembagian kekuasaan negara. $^{5}$

Demokrasi merupakan pemerintahan dari, oleh, dan untuk rakyat di mana rakyatlah sebagai pemilik kekuasan tertinggi pada suatu negara. Setiap kebijakan pemerintah harus berdasarkan kepentingan rakyat. ${ }^{6}$

Definisi demokrasi adalah sebuah bentuk kekuasaan (kratein) dari/oleh/untuk rakyat (demos). Menurut konsep demokrasi, kekuasaan menyiratkan arti politik dan pemerintahan, sedangkan rakyat beserta warga masyarakat didefinisikan sebagai warga negara. Kenyataannya, baik dari segi konsep maupun praktek demos menyiratkan makna diskriminatif. Demos bukanlah rakyat keseluruhan, tetapi hanya populis tertentu, yaitu mereka yang berdasarkan tradisi atau kesepakatan formal mengontrol akses ke sumber-sumber kekuasaan dan mengklaim kepemilikan atas hak-hak prerogatif dalam proses pengambilan keputusan yang berkaitan dengan urusan publik atau pemerintahan. ${ }^{7}$

5 Jailani, Sistem Demokrasi di Indonesia Ditinjau dari Sudut Hukum Ketatanegaraan, Jurnal Inovatif, Volume VIII Nomor I Januari 2015, hlm. 135

6 Abdul Latief, Hukum Dan Peraturan Kebijaksanaan (Beleidsregel) Pada Pemerintahan Daerah, (Yogyakarta : UII Press, 2009), hlm.56

${ }^{7}$ Imam Syaukani, Dasar-Dasar Politik Hukum, (Jakarta : PT Raja Grafindo, 2004), hlm. 37 
Menurut Miriam Budiharjo demokrasi itu dapat dibedakan atas dua aliran yaitu :

a. Demokrasi konstitusional, berawal dari gagasan bahwa pemerintah yang demokratik adalah pemerintah yang terbatas kekuasaannya dan tidak sewenang-wenang terhadap warga negara.

b. Demokrasi proletar/demokrasi rakyat, mendasarkan pada ideologi komunisme yang banyak dianut oleh negara-negara komunis di eropa timur, juga Republik Rakyat Cina dan Korea Utara di Asia. ${ }^{8}$

\section{Pancasila dalam Sistem Hukum Indonesia}

Hukum timbul dari rasa wajib yang tertanam dalam jiwa manusia, yakni dalam akal budi dan budi-nurani manusia, yang mengharuskan manusia bersikap dan berperilaku dengan cara tertentu terhadap dan berkenaan dengan adanya manusia (manusia-manusia) lain, untuk mewujudkan ketertiban dan keteraturan dalam masyarakat, sedemikian rupa sehingga martabat dan kodrat manusia tidak tertindas. Keharusan itu menimbulkan hak untuk menuntut agar apa yang diharuskan dilaksanakan. Kewajiban tersebut sekaligus

\footnotetext{
8 Miriam Budiharjo, Dasar-Dasar IImu Politik, (Jakarta : Gramedia Pustaka Utama, 1986), hlm. 42
}

menimbulkan hak. Kewajiban bersikap dan berperilaku tertentu terhadap orang lain itu dirasakan sebagai apa yang sudah sepantasnya dan seadilnya menjadi hak orang lain itu. Manusia merasa wajib dan dituntut untuk memberikan kepada orang lain apa yang menjadi bagiannya atau haknya.

Hak dan kewajiban timbul dalam hubungan antar-manusia karena bersifat mengatur, serta selalu berarti dan hanya dapat dipahami sebagai hak dan kewajiban terhadap manusia atau manusia-manusia lain. Jadi, hak dan kewajiban itu menunjuk atau mengungkapkan hubungan antarmanusia. Hukum pada hakikatnya adalah hubungan antar manusia dalam dinamika kehidupan bermasyarakat. Hukum yang mewujudkan diri sebagai proses-proses sosial pengaturan atau pengkaidahan cara berperilaku. Proses sosial itu menghasilkan kaidah-kaidah hukum. Hukum adalah pengaturan perilaku manusia dalam menyelenggarakan hubungan antar sesamanya di dalam masyarakat.

Hukum yang dijiwai oleh Pancasila adalah hukum yang berasaskan semangat kerukunan. Hukum secara langsung diarahkan untuk mewujudkan keadilan sosial yang memberikan kepada masyarakat sebagai kesatuan dan masingmasing warga masyarakat kesejahteraan (material dan spiritual) yang merata dalam 
keseimbangan yang proporsional. Terpaut pada asas kerukunan adalah asas kepatutan. Asas ini juga adalah asas tentang cara menyelenggarakan hubungan antar warga masyarakat yang di dalamnya para warga masyarakat diharapkan untuk berperilaku dalam kepantasan yang sesuai dengan kenyataan-kenyataan sosial. Menurut hukum dalam melaksanakan hak dan kewajiban yang sah, para warga masyarakat diharapkan untuk memperhatikan kepantasan, yakni dari para warga masyarakat diharapkan berperilaku sedemikian rupa hingga tidak merendahkan martabatnya sendiri dan atau orang lain. Sifat lain yang memberikan ciri pada Hukum Pancasila adalah asas keselarasan. Asas ini menghendaki terselenggaranya harmoni dalam kehidupan bermasyarakat. ${ }^{9}$

Berdasarkan asas tersebut, maka penyelesaian masalah-masalah konkret, selain harus didasarkan pada pertimbangan kebenaran dan kaidah-kaidah hukum yang berlaku, juga harus dapat diakomodasikan pada proses-proses kemasyarakatan sebagai keseluruhan yang utuh dengan

9 Deny Indrayana, Penerapan Konsepsi Pancasila Sebagai Sumber dari Segala Sumber Hukum dalam Penyusunan Perundang-undangan (Studi Kasus UU No.11 Tahun 2006 tentang Pemerintahan Nangroe Aceh Darussalam), (Yogyakarta : FH UGM, 2007), hlm. 48 mempertimbangkan perasaan-perasaan yang hidup dalam masyarakat. Para warga masyarakat dan pelaksana hukum diharapkan dapat melaksanakan hak dan kewajibannya, sedemikian rupa sehingga kerukunan dan kesejahteraan bermasyarakat dapat dipertahankan dan dikembangkan. Asas kerukunan, asas kepatutan dan asas keselarasan sebagai ciri-ciri khas dari Hukum Pancasila dapat dicakup dengan satu istilah, yakni sifat kekeluargaan. Hukum Pancasila adalah hukum bersemangat kekeluargaan. Semangat kekeluargaan menunjuk pada sikap yang berdasarkannya kepribadian setiap warga masyarakat diakui dan dilindungi oleh masyarakat.

Tatanan hukum yang diterapkan di masyarakat pada dasarnya merupakan pengejawantahan cita-hukum yang bersangkutan ke dalam berbagai perangkat aturan hukum positif, lembaga hukum dan proses (perilaku birokrasi pemerintahan dan warga masyarakat). Cita hukum merupakan gagasan, karsa, cipta dan pikiran berkenaan dengan hukum atau persepsi tentang makna hukum, yang dalam intinya terdiri atas tiga unsur: keadilan, kehasil-gunaan dan kepastian hukum. Cita hukum terbentuk dalam pikiran dan sanubari manusia sebagai produk berpadunya pandangan hidup, keyakinan keagamaan dan kenyataan 
kemasyarakatan yang diproyeksikan pada proses pengkaidahan perilaku warga masyarakat yang mewujudkan tiga unsur cita hukum tersebut. Dalam dinamika kehidupan kemasyarakatan, cita hukum akan mempengaruhi dan berfungsi sebagai asas umum yang mempedomani, norma kritik (kaidah evaluasi) dan faktor yang memotivasi dalam penyelenggaraan hukum (pembentukan, penemuan dan penerapan hukum) dan perilaku hukum. ${ }^{10}$

Dirumuskan dan dipahaminya citahukum akan memudahkan penjabarannya ke dalam berbagai perangkat aturan kewenangan dan aturan perilaku, dan memudahkan terjaganya konsistensi dalam penyelenggaraan hukum. Tata hukum seyogianya merupakan sebuah eksemplar ramifikasi cita hukum ke dalam berbagai asas dan kaidah hukum yang tertata (tersusun) dalam sebuah sistem. Sejalan dengan itu, Ilmu Hukum yang mempelajari tatanan hukum sebagai sarana intelektual untuk memahami dan menyelenggarakan tatanan hukum tersebut, dalam pengembanannya seharusnya bertumpu dan mengacu pada cita-hukum itu. Cita hukum bangsa Indonesia berakar dalam

10 Kaelan, Pendidikan Pancasila "Proses Reformasi, UUD Amandemen 2002, Pancasila Sebagai Sistem Filsafat, Pancasila Sebagai Etika Politik, Paradigma Bermasyarakat, Berbangsa, dan Bernegara", (Yogyakarta : Paradigma, 2003), hlm.29
Pancasila yang oleh para Bapak Pendiri Negara Republik Indonesia ditetapkan sebagai landasan kefilsafatan dalam menata kerangka dan struktur dasar organisasi negara sebagaimana dirumuskan dalam Undang-Undang Dasar 1945.

Pancasila merupakan pandangan hidup bangsa Indonesia mengenai hubungan antara manusia dan Tuhan, manusia dan sesama manusia, serta manusia dan alam semesta, yang berintikan keyakinan tentang tempat manusia individual di dalam masyarakat dan alam semesta. Dalam dinamika kehidupan, pandangan hidup yang dianut akan memberikan koherensi dan direksi (arah) pada pikiran dan tindakan. ${ }^{11}$

Cita hukum Pancasila yang berakar dalam pandangan hidup Pancasila dengan sendiri akan mencerminkan tujuan menegara dan nilai-nilai dasar yang tercantum dalam Pembukaan, Batang Tubuh serta Penjelasan Undang Undang Dasar 1945. Pandangan hidup Pancasila bertolak dari keyakinan bahwa alam semesta dengan segala isinya, termasuk manusia, sebagai suatu keseluruhan

\footnotetext{
${ }^{11}$ Jazim Hamidi, Revolusi Hukum Indonesia: Makna, Kedudukan dan Implikasi Hukum Naskah Proklamasi 17 Agustus 1945 dalam Sistem Ketatanegaraan RI, (Jakarta : Konstitusi Press dan Citra Media, 2006), hlm.31
} 
terjalin secara harmonis, diciptakan oleh Tuhan. Kehadiran manusia di dunia dikodratkan dalam kebersamaan dengan sesamanya, namun tiap manusia memiliki kepribadian unik berbeda satu dari lainnya. Keseluruhan pribadi manusia dengan keunikannya masing-masing mewujudkan satu kesatuan, yakni kemanusiaan. Kesatuan dalam perbedaan maksudnya dalam kebersamaan (kesatuan) tiap individu warga kesatuan memperlihatkan kodrat kepribadian unik, yang berarti terdapatnya perbedaan di dalam kesatuan kemanusiaan.

Kodrat kepribadian ini tidak dapat disangkal tanpa meniadakan kodrat kemanusiaannya. Tiap manusia dan masyarakat harus mengakui, menerima, memelihara dan melindungi kepribadian tiap manusia sebagai warga masyarakat. Hal tersebut tidak berarti bahwa kepentingan tiap manusia secara individu harus didahulukan dari masyarakat. Setiap manusia memiliki kodrat untuk hidup bersama, tiap manusia individual hanya dapat mewujudkan kemanusiaannya di dalam masyarakat. Kehadiran dan kehidupan manusia tidak terlepas dari ketergantungan pada kebersamaan dengan sesamanya dalam masyarakat. Kebahagiaan dan upaya untuk mewujudkannya tidak terisolasi dari kebahagiaan masyarakat sebagai keseluruhan. Manusia tidak terlepas dari ketergantungan pada lingkungan alam dan Tuhan. Kebersamaan dengan sesamanya serta ketergantungan pada alam dan Tuhan adalah struktur dasar yang hakiki dari keberadaan manusia. Struktur dasar kebersamaan dengan sesamanya dan keterikatan pada alam dan Tuhan ini dirumuskan dalam bentuk sila-sila dari Pancasila.

Pandangan hidup Pancasila dirumuskan dalam kesatuan lima sila yang masing-masing mengungkapkan nilai fundamental dan sekaligus menjadi lima asas operasional dalam menjalani kehidupan, termasuk dalam penyelenggaraan kegiatan bernegara dan pengembanan hukum praktis. Kesatuan lima nilai fundamental itu bersama-sama dengan berbagai nilai dielaborasi (diejawantahkan) ke dalam berbagai asas hukum dan kaidah hukum yang keseluruhannya mewujudkan sebuah sistem hukum (tata-hukum). Tiap kaidah hukum mencerminkan atau dijiwai sebuah nilai, dan tata-hukum mencerminkan atau bermuatan sistem-nilai. ${ }^{12}$

\footnotetext{
12 Oetoyo Oesman dan Alfian, Pancasila sebagai Ideologi dalam Berbagai Kehidupan Bermasyarakat, Berbangsa, dan Bernegara, (Jakarta : BP-7 Pusat, 1991), hlm. 36
} 


\section{Paradigma Demokrasi Pancasila Dalam Pembangunan Hukum Di Indonesia}

Prinsip-prinsip demokrasi telah disusun sesuai dengan nilai-nilai yang tumbuh dalam masyarakat, meski harus dikatakan baru sebatas demokrasi prosedural, dalam proses pengambilan keputusan lebih mengedepan voting ketimbang musyawarah untuk mufakat, yang sejatinya merupakan azas asli demokrasi Indonesia. Praktek demokrasi ini tanpa dilandasi mental state yang berakar dari nilai-nilai luhur bangsa merupakan gerakan omong kosong belaka. Konsep demokrasi pancasila digali dari nilai masyarakat asli Indonesia dengan nilai-nilai yang melekat kepadanya, seperti desa demokrasi, rapat kolektivisme, musyawarah mufakat, tolong menolong dan istilah-istilah lain yang berkaitan dengan itu. Tujuannya, memberikan dasar empiris sosiologis tentang konsep demokrasi yang sesuai dengan sifat kehidupan masyarakat asli Indonesia, bukan sesuatu yang asing yang berasal dari barat dan dipaksakan pada realitas kehidupan bangsa Indonesia. ${ }^{13}$

Masyarakat asli yang dimaksudkan disini adalah bentuk kehidupan masyarakat

${ }^{13}$ Yudi Latif, Negara Paripurna; Historisitas, Rasionalitas dan Aktualitas Pancasila, (Jakarta : Pustaka Gramedia, 2011), hlm. 383 yang sudah berlangsung dipulau-pulau di nusantara sejak berabad-abad yang lalu dan yang tersusun dari satuan-satuan kehidupan yang terkecil yang berbedabeda seperti desa di Jawa, nagari di Sumatra Barat, pekon di Lampung atau subak di Bali. Masyarakat asli ini memiliki seperangkat nilai mental dan moral yang bersifat homogen, struktural dan kolektif, yang kesemuanya memiliki sistem budaya sendiri dan berlangsung secara demokratis, yaitu demokrasi secara langsung sebagaimana terdapat dinegara-negara kota di yunani kuno 25 abad yang lalu. Proses metamorfosis nilai-nilai demokrasi yang digali dari kearifan budaya Indonesia tersebut mengalami beberapa perioderisasi dalam proses implementasinya sebagai suatu keniscayaan, dan tahapan tersebut dapat dilihat dalam uraian berikut ini. Pelaksanaan demokrasi di Indonesia dapat dibagi ke dalam lima priode :

1. Pelaksanaan demokrasi masa revolusi di tahun 1945-1950.

2. Pelaksanaan demokrasi masa orde lama.

a. Masa demokrasi liberal tahun 1950-1959.

b. Masa demokrasi terpimpim tahun 1959-1965.

3. Pelaksanaan demokrasi masa orde baru tahun 1966-1998. 
4. Pelaksanaan demokrasi masa transisi tahun 1998-1999.

5. Pelaksanaan demokrasi masa reformasi tahun 1999 sampai sekarang. ${ }^{14}$

Indonesia mengadopsi sistem demokrasi sejak proklamasi. Sistem demokrasi yang diterapkan di Indonesia memerlukan penjelasan yang lebih detail. Sistem demokrasi meliputi berbagai macam jenis, contohnya, ada demokrasi liberal dan demokrasi pancasila.

Pancasila sebagai suatu bentuk demokrasi mengkristal dalam UUD NRI 1945 yang berlaku jauh sebelum tahun 1965 namun populer sesudah orde baru (tahun 1966). Demokrasi Pancasila mengutamakan musyawarah mufakat, apabila mufakat tidak tercapai maka ditempuh jalan voting (pemungutan suara) sebagaimana dimaksud Pasal 2 ayat (3) dan Pasal 6 ayat (2) UUD NRI 1945. Makna mengenai Demokrasi Pancasila sebagai demokrasi kedaulatan rakyat yang dijiwai dan diintegrasikan dengan sila-sila yang dilaksanakan dengan rasa tanggungjawab kepada Tuhan Yang Maha Esa. Hal tersebut disampaikan Presiden

14 Suleman, Zulfikri, Demokrasi Untuk Indonesia, (Jakarta: Kompas,2010), hlm.32
Soeharto pada pidato kenegaraan tanggal 16 Agustus $1967 .^{15}$

Demokrasi Pancasila pada hakikatnya merupakan norma yang mengatur penyelenggaraan kedaulatan rakyat dan penyelenggaraan pemerintahan negara, dalam kehidupan politik, ekonomi, sosial budaya, dan pertahanan keamanan, bagi setiap warga negara Republik Indonesia, organisasi kekuatan sosial politik, organisasi kemasyarakatan, dan lembaga kemasyarakatan lainnya serta lembagalembaga negara baik di pusat maupun di daerah. Demokasi Pancasila memiliki prinsip-prinsip yang berlaku, seperti:

1) Kebebasan atau persamaan (Freedom/ Equality), merupakan dasar demokrasi. Kebebasan dianggap sebagai sarana mencapai kemajuan dan memberikan hasil maksimal dari usaha orang tanpa pembatasan dari penguasa. Prinsip persamaan semua orang dianggap sama, tanpa dibedabedakan dan memperoleh akses dan kesempatan bersama untuk mengembangkan diri sesuai dengan potensinya. Kebebasan yang dikandung dalam demokrasi Pancasila ini tidak berarti Free Fight Liberalism

${ }^{15}$ Ajat Sudrajat, Demokrasi Pancasila Dalam Perspektif Sejarah, Mozaik Jurnal IImu-IImu Sosial dan Humaniora Volume 8 No. 1 2016, hlm. 14. 
yang tumbuh di Barat, tapi kebebasan yang tidak mengganggu hak dan kebebasan orang lain.

2) Kedaulatan Rakyat (people's Sovereignty), hakikatnya kebijakan yang dibuat adalah kehendak rakyat dan untuk kepentingan rakyat. Mekanisme semacam ini akan mencapai dua hal yaitu kemungkinan terjadinya penyalahgunaan kekuasaan sangatlah kecil, dan kepentingan rakyat dalam tugas-tugas pemerintahan lebih terjamin. Perwujudan lain dari konsep kedaulatan adalah adanya pengawasan oleh rakyat. Pengawasan dilakukan karena demokrasi tidak mempercayai kebaikan hati penguasa. ${ }^{16}$

Menurut Hatta, Pancasila sila Ketuhanan Yang Maha Esa menjadi dasar yang memimpin sila-sila yang lain. Seperti halnya sila kerakyatan atau demokrasi akan hidup selama-lamanya di bumi Indonesia, sekalipun akan mengalami pasang surut. Sumber demokrasi di Indonesia ada tiga, pertama, sosialisme Barat yang membela prinsip-prinsip humanisme, dan prinsip ini juga dipandang sebagai tujuan. Kedua, ajaran Islam yang memerintahkan kebenaran dan keadilan

16 Jimly Asshiddiqie, Hukum Tata Negara \& Pilar-Pilar Demokrasi, (Jakarta; Sinar Grafika, 2011), hlm. 198-234
Tuhan dalam bermasyarakat. Ketiga, pola hidup dalam bentuk kolektivisme sebagaimana terdapat di desa-desa di Indonesia. Ketiga sumber inilah yang akan menjamin kelestarian demokrasi di Indonesia, sehingga Hatta berkeyakinan bahwa demokrasi di Indonesia mempunyai dasar yang kukuh. ${ }^{17}$

Demokrasi Pancasila juga diartikan sebagai demokrasi yang dihayati oleh bangsa dan negara Indonesia yang dijiwai dan diintegrasikan oleh nilai-nilai luhur Pancasila. Dalam menganut asas demokrasi Pancasila, sistem pengorganisasian negara dilakukan oleh rakyat sendiri atau dengan persetujuan rakyat, dimana keluhuran manusia sebagai makhluk Tuhan dalam bidang politik, ekonomi, sosial budaya dan pertahanan keamanan diakui, ditaati dan dijamin atas dasar kenegaraan Pancasila. Kedaulatan rakyat dengan sistem perwakilan atau demokrasi biasa disebut sistem demokrasi perwakilan (representative democracy) atau demokrasi tidak langsung (indirect democracy). Dalam praktek, pihak yang menjalankan kedaulatan rakyat itu adalah wakil-wakil rakyat yang duduk di lembaga perwakilan rakyat yang disebut parlemen. Agar wakil-wakil rakyat dapat bertindak

\footnotetext{
17 Mohamad Hatta, Menuju Negara Hukum, (Jakarta: Idayu Press, 1977), hlm.17.
} 
atas nama rakyat, wakil-wakil rakyat itu harus ditentukan sendiri oleh rakyat, yaitu melalui pemilihan umum (general election). Pemilihan umum tidak lain merupakan cara yang diselenggarakan untuk memilih wakil-wakil rakyat secara demokratis.

Pancasila sebagai dasar Negara Republik Indonesia memiliki nilai-nilai yang merupakan hasil kesepakatan luhur (modus vivendi) dari para pendiri negara yang digali dari karakteristik bangsa Indonesia itu sendiri yang dikristalisasikan ke dalam sila-sila pancasila. Artinya, silasila pancasila merupakan cerminan dari jiwa bangsa Indonesia seperti nilai keagamaan, keadilan, kebersamaan, kegotong-royongan, tenggang rasa, toleransi, dan permusyawaratan yang melekat dan menjadi ciri khas bangsa Indonesia.

Pancasila menjadi petunjuk dalam kehidupan bermasyarakat, berbangsa, dan bernegara Indonesia dalam setiap subsistem kemasyarakatan. Dalam membangun sub-sistem kemasyarakatan harus berdasarkan kepada pancasila agar tumbuh dengan baik sesuai dengan karakteristik bangsa Indonesia. Sub-sistem kemasyarakatan tersebut dimanivestasikan ke dalam ideologi, politik, ekonomi, sosial budaya, dan pertahanan keamanan. Agar Indonesia dapat menjadi negara yang kuat seluruh subsistem kemasyarakatan tersebut harus senantiasa diperkuat dalam wujud ketahanan nasional. ${ }^{18}$

Mengacu pada kelima nilai dasar yang dikandung oleh filsafat dan ideologi Pancasila tersebut dapat dibangun suatu kerangka paradigmatik pembangunan demokrasi Indonesia. Kerangka paradigmatik tersebut diuraikan sebagai berikut:

\section{a. Negara hukum yang Berketuhanan Yang Maha Esa}

Paradigma pembangunan demokrasi Indonesia yang berbasis Pancasila bertolak dari kesadaran kritis bahwa eksistensi illahiah merupakan eksistensi tertinggi dalam realitas eksistensi keberadaan. Tuhan merupakan sumber dari segala sumber yang mengadakan manusia dan seluruh alam, eksistensi Ketuhanan inilah meniscayakan nilai-nilai illahiah atau nilai-nilai religi.

\section{b. Negara Hukum yang Berkemanusiaan Yang Adil dan Beradab}

Paradigma pembangunan demokrasi Indonesia yang berbasis Pancasila mengisyaratkan negara hukum dibangun

\footnotetext{
${ }^{18}$ Muladi, Menggali Kembali Pancasila Sebagai Dasar Pengembangan IImu Hukum Indonesia", Jurnal Hukum Progresif, Volume 1 Nomor 1, April 2005, hlm.6
} 
demi memberikan perlindungan dan penghormatan terhadap keberadaan martabat manusia. Dalam paradigma ini tidak dibenarkan adanya kesewenangwenangan terhadap manusia yang lain, baik dalam bentuk kesewenang-wenangan aparat kekuasaan terhadap rakyat maupun kesewenang-wenangan kelompok mayoritas terhadap minoritas.

\section{c. Negara Hukum yang Berpersatuan Indonesia}

Paradigma demokrasi Indonesia berbasis Pancasila beranjak dari kesadaran kontekstual bahwa susunan sosiologis dan geografis masyarakat Indonesia terbangun dari latar geokultural yang beraneka ragam dimana masing-masing kultur baik agama maupun etnis memiliki investasi historis yang tidak bisa diabaikan dalam proses panjang menjadi komunitas bersama yang bernama negara Indonesia.

\section{d. Negara Hukum yang Berkerakyatan yang Dipimpin oleh Hikmat Kebijaksanaan dalam Permusyawaratan/ Perwakilan}

Paradigma pembangunan demokrasi Indonesia berbasis Pancasila mengandaikan tumbuh dan berkembangnya negara hukum yang demokratis (democratische rechtstaat), yang menyandingkan prinsip-prinsip negara hukum (nomokrasi) dengan prinsip-prinsip kedaulatan rakyat (demokrasi demokrasi) itu sendiri secara selaras dan saling melengkapi. Keberadaan Negara hukum tanpa pemerintahan demokratis akan berubah menjadi negara yang fasis dan represif, sebaliknya pemerintahan demokratis tanpa hukum akan terjebak pada perjalanan negara ke dalam anarki.

\section{e. Negara Hukum yang Berkeadilan Sosial bagi Seluruh Rakyat Indonesia}

Paradigma pembangunan demokrasi Indonesia berbasis Pancasila mengandung arti bahwa negara hukum Indonesia bervisi negara kesejahteraan (welfare state) yang tidak sekedar mengejar keadilan dan kebahagiaan warga negaranya secara liberalis dan individualistik. Jalan pikiran yang demikian berarti hukum tidak semata hadir sebagai kekuatan untuk mendamaikan konflik dan penjaga ketertiban masyarakat (a tool of social order) sebagaimana yang secara khas diasumsikan dalam pandangan demokrasi Indonesia.

\section{Kesimpulan}

Paradigma Demokrasi Pancasila dalam pembangunan hukum di Indonesia merupakan bentuk atau sistem pemerintahan dengan segenap rakyat yang turut serta memerintah dengan perantaraan 
wakil-wakilnya atau pemerintahan rakyat. Konsep demokrasi Pancasila tidak bersumber dari paham individualisme yang berkembang di barat meski tak bisa di tampik nilai-nilai liberal yang membentuk demokrasi di barat seperti kesetaraan hak warga negara, kebebasan berpendapat sebagai pilar demokrasi yang utama berpengaruh kuat terhadap pengayaan demokrasi Pancasila. Pembangunan hukum nasional Indonesia harus memperhatikan supremasi hukum dan penegakan hak asasi manusia yang bersumber Pancasila dan Undang-Undang Dasar 1945 termasuk mewujudkan pembaharuan hukum nasional yang sesuai dengan nilai-nilai Pancasila. Pembangunan hukum nasional disesuaikan dengan watak karakteristik budaya masyarakat di Indonesia. Karakteristik masyarakat Indonesia lebih bersifat monodualistik dan pluralistik. Hukum nasional berorientasi pada nilai-nilai hukum dan norma yang hidup dalam masyarakat. Nilai-nilai budaya yang hidup di masyarakat lebih dijiwai oleh nilai-nilai hukum adat dan hukum agama. Pembangunan hukum nasional pada hakekatnya adalah membangun konsep-konsep tatanan yang dijiwai nilai-nilai Pancasila, yaitu nilai moral religius atau ketuhanan, nilai humanistik atau kemanusiaan, nilai nasionalisme atau kebangsaan, nilai demokrasi atau kerakyatan, dan nilai keadilan sosial.

\section{Daftar Pustaka}

\section{Buku}

Abdul Latief, Hukum Dan Peraturan Kebijaksanaan (Beleidsregel) Pada Pemerintahan daerah, Yogyakarta : UIIPress, 2009.

Deny Indrayana, Penerapan Konsepsi Pancasila Sebagai Sumber dari Segala Sumber Hukum dalam Penyusunan Perundang-undangan (Studi Kasus UU No.11 Tahun 2006 tentang Pemerintahan Nangroe Aceh Darussalam), FH UGM, 2007.

Imam Syaukani, Dasar-Dasar Politik Hukum, Jakarta : PT Raja Grafindo, 2010.

Jimly Asshiddiqie, Hukum Tata Negara \& Pilar-Pilar Demokrasi, Jakarta; Sinar Grafika, 2011.

Jazim Hamidi, Revolusi Hukum Indonesia: Makna, Kedudukan dan Implikasi Hukum Naskah Proklamasi 17 Agustus 1945 dalam Sistem Ketatanegaraan RI, Jakarta : Konstitusi Press dan Citra Media, 2006.

Kaelan, Pendidikan Pancasila "Proses Reformasi, UUD Amandemen 2002, Pancasila Sebagai Sistem Filsafat, Pancasila Sebagai Etika Politik, Paradigma Bermasyarakat, Berbangsa, dan Bernegara”, Paradigma : Yogyakarta, 2003.

Mohammad Hatta, Karya Lengkap Bung Hatta.Buku I : Kebangsaan dan Kerakyatan, Jakarta: Penerbit LP3ES, 1998. 
Maulana Arafat Lubis, Hukum Tata Negara, Medan: Akasha Sakti, 2018.

Mohamad Hatta, Menuju Negara Hukum, Jakarta: Idayu Press, 1977.

Miriam Budiharjo, Dasar-Dasar Ilmu Politik, Jakarta : Gramedia Pustaka Utama, 1986.

Nadrilun, Mengenal lebih dekat demokrasi di Indonesia, Jakarta Timur: PT Balai Pustaka, 2012.

Suleman, Zulfikri, Demokrasi Untuk Indonesia,Jakarta: Kompas,2010.

Yudi Latif, Negara Paripurna; Historisitas, Rasionalitas dan Aktualitas Pancasila, Jakarta; Pustaka Gramedia, 2011.

Mubyarto, Ideologi Pancasila dalam Kehidupan Ekonomi, Dalam Buku Pancasila Sebagai Ideologi. Jakarta: BP-7 Pusat. 1991.

Oetoyo Oesman dan Alfian, Pancasila sebagai Ideologi dalam Berbagai Kehidupan Bermasyarakat, Berbangsa, dan Bernegara, BP-7 Pusat, Jakarta, 1991.

Yudi Latif, Negara Paripurna; Historisitas, Rasionalitas dan Aktualitas Pancasila, Jakarta; Pustaka Gramedia, 2011.

Zulfikri Suleman, Demokrasi Untuk Indonesia, Jakarta: Kompas, 2010.

\section{Karya Ilmiah}

Ajat Sudrajat, Demokrasi Pancasila Dalam Perspektif Sejarah, Mozaik Jurnal Ilmu-Ilmu Sosial dan Humaniora Volume 8 No. 12016
Jailani, Sistem Demokrasi di Indonesia Ditinjau dari Sudut Hukum Ketatanegaraan, Jurnal Inovatif, Volume VIII Nomor I Januari 2015,

Muladi, Menggali Kembali Pancasila Sebagai Dasar Pengembangan Ilmu Hukum Indonesia”, Jurnal Hukum Progresif, Volume 1 Nomor 1, April 2005.

\section{Peraturan Perundang - Undangan}

Undang-Undang Dasar Republik Indonesia Tahun 1945 